\title{
Hubungan Tingkat Risiko Kehamilan dengan Kejadian Komplikasi Persalinan di RSUD Panembahan Senopati Bantul
}

\author{
Prima Hidayah¹, Heni Puji Wahyuningsih², dan Kusminatun ${ }^{3}$ \\ Program Studi Diploma IV Kebidanan Sekolah Vokasi Universitas Gadjah Mada ${ }^{1,2,3}$ \\ primahidayah93@gmail.com ${ }^{1}$, henipujiw@gmail.com², kusminatun@gmail.com ${ }^{3}$
}

\begin{abstract}
ABSTRAK
Latar Belakang: Komplikasi persalinan merupakan penyebab langsung dari kesakitan dan kematian pada maternal. Hal ini disebabkan karena proses persalinan dihadapkan pada kondisi kritis terhadap masalah kegawatdaruratan sehingga salah satu upaya untuk mengantisipasi risiko yang akan terjadi dengan mendeteksi faktor risiko secara dini.

Tujuan: Penelitian ini bertujuan untuk mengetahui hubungan antara tingkat risiko ibu hamil dengan kejadian komplikasi persalinan.

Metode: Metode penelitian menggunakan survei analitik dengan rancangan cross sectional corelasional. Penelitian ini dilakukan pada tanggal 14 Desember 2015-27 Januari 2016. Populasi target adalah seluruh ibu bersalin (2683) yang ada di RSUD Panembahan Senopati Bantul selama Tahun 2014 dan jumlah sampel 336. Data diambil dari rekam medis dengan teknik pengambilan sampel secara non randomized. Kriteria inklusi Umur Kehamilan 38 minggu dan kehamilan berisiko. Penelitian ini dianalisis secara univariabel, bivariabel dengan uji Chi Square dan Ratio Prevalence (RP) dan multivariabel dengan uji regresi logistik.

Hasil: Hasil analisis bivariabel menunjukkan bahwa variabel yang berhubungan dengan kejadian komplikasi persalinan adalah tingkat risiko dan tingkat pendidikan. KRST (RP 4,4; CI 95\% 2,491-7,722); KRT (RP 1,8; CI 95\% 1,045-3,225); KRT terhadap KRR (RP 2,4; CI 95\% 1,397-4,085). Hasil analisis multivariabel menunjukkan bahwa tingkat risiko kehamilan sig 0,000 (RP 2,032; CI 95\% 1,517-2,722) dan tingkat pendidikan sig 0,359 (RP 0,795; CI 95\% 0,487-1,298).
\end{abstract}

Kesimpulan: Kesimpulan bahwa ada hubungan antara tingkat risiko kehamilan dengan kejadian komplikasi persalinan.

Kata kunci: komplikasi persalinan; tingkat risiko kehamilan.

\begin{abstract}
Background : Complications of labor is a direct causes of maternal morbidity and mortality. This is because an estimated $15 \%$ of pregnancies and deliveries will experience complications so the attempts to anticipate the risks is early detection of risk factors.

Objective : The aims is to determine the relationship between the level of pregnant women's risk with the incidence of labor complications.

Methods : The method is analytic survey with cross sectional design corelasional. This research was conducted at 14 December 2015-27 January 2016. The population target is all of maternity (2683 subjects) in Panembahan Senopati Bantul District Hospital during 2014 and total population is 336 samples. It taken from medical record with non randomized sampling technique. The inclusion criteria is 38 weeks of pregnancy and pregnancy risk. This analysis research was performed univariable, bivariable with Chi Square test and Ratio Prevalence (PR) and multivariable with logistic regression test.

Results : Bivariable analysis results showed that the level of risk and level of education related to incidence of labor complications. KRST (RP 4.4; 95\% CI 2.491-7.722); KRT (RP 1.8; 95\% CI 1.045-3.225); KRT to KRR (RP 2.4; 95\% CI 1.397-4.085). Results of multivariable analysis showed that the level risk of pregnancy has sig 0,000 (RP 2.032; 95\% CI 1.517-2.722) and education level has sig 0.359 (RP 0.795; 95\% CI 0.487-1.298).

Conclusion: The conclusion is the level of pregnancy risk has a relationship with the incidence of labor complications.
\end{abstract}

Keywords: complications of labor; level of pregnancy risk. 


\section{PENDAHULUAN}

kebijakan Kesehatan Ibu dan Anak (KIA) pernah secara agresif diimlementasikan di Indonesia. Angka kematian ibu mengalami penurunan dari 390 menjadi 228 per 100.000 kelahiran hidup semenjak tahun 1997 hingga 2007 (Prakarsa, 2013; Kemenkes RI, 2014). Namun berdasarkan data SDKI pada tahun 2012 mengalami peningkatan yaitu 359 per 100.000 kelahiran hidup. Angka ini sangat jauh dari target MDGs yaitu 102 per 100.000 kelahiran hidup pada tahun 2015. Penurunan kematian ibu dengan upaya peningkatan persalinan yang ditolong oleh tenaga kesehatan merupakan indikator dari tujuan pembangunan MDGs yang paling penting (Kemenkes RI, 2013).

Kematian ibu dapat terjadi sebagai akibat langsung dari komplikasi yang berkembang pada kehamilan, persalinan atau faktor postpartum dan sebagai akibat tidak langsung karena memburuknya pelayanan klinis yang ada (Litbangkes Kemenkes RI, 2013). Kejadian komplikasi persalinan dapat disebabkan karena adanya faktor-faktor risiko pada saat kehamilan.

Namun, hal ini tidak dapat menjadi tolak ukur akan kejadian tersebut, karena komplikasi persalinan dapat juga terjadi pada ibu hamil yang tidak mempunyai faktor-faktor risiko. Oleh sebab itu, bidan sebagai petugas pelayanan kesehatan yang memiliki hubungan langsung dengan ibu hamil dalam pemberian asuhan atau perawatan kehamilan (antenatal care) berperan penting untuk mengelola pencegahan risiko melalui skrinning sehingga dapat menentukan tingkat risiko sesuai dengan tingkat kegawatan dari faktor risiko tersebut.

Komplikasi persalinan dapat diartikan sebagai suatu keadaan yang mengancam jiwa ibu ataupun janin karena gangguan sebagai akibat langsung dari proses persalinan (Basu et al., 2014).

Berdasarkan SDKI 2012 identifikasi komplikasi yang berhubungan dengan persalinan antara lain persalinan lama, ketuban pecah dini, perdarahan, infeksi, dan eklampsia. Hal ini sebenarnya dapat dicegah dan ditangani apabila ibu segera mencari pertolongan ke tenaga kesehatan, Adapun hal-hal yang dapat dilakukan adalah pertama tenaga kesehatan melakukan prosedur penanganan yang sesuai antara lain penggunaan partograf untuk memantau perkembangan persalinan.

kedua pelaksanaan manajemen aktif kala III dilakukan untuk mencegah perdarahan pasca-salin, ketiga tenaga kesehatan mampu melakukan identifikasi dini komplikasi, keempat memberikan pertolongan pertama dan terakhir melakukan tindakan stabilisasi pasien sebelum melakukan rujukan, proses rujukan efektif, dan pelayanan di rumah sakit yang cepat dan tepat guna (Kemenkes RI, 2013).

Risiko kehamilan menjadi sebuah alat ukur statistik dalam studi epidemiologi berdasarkan kemungkinan terjadinya suatu keadaan gawat darurat obstetrik yang tidak diinginkan pada masa mendatang (Umah, 2015). Menurut Sarwono Prawiroharjo faktor risiko dikelompokkan dalam 3 kelompok yaiti FR I (Ada Potensi Gawat Obstetrik/ APGO), FR II (Ada Gawat Obstetrik/ AGO) dan FR III (Ada Gawat Darurat Obtetrik/ AGDO) (Prawirohardjo, 2010).

Kartu Skor Poedji Rochajti (KSPR) adalah alat untuk mendeteksi dini kehamilan berisiko dengan menggunakan skoring. Jumlah skor kehamilan dibagi menjadi tiga kelompok yaitu Kehamilan Risiko Rendah (jumlah skor 2 dengan kode warna hijau), Kehamilan Risiko Tinggi (jumlah skor 6-10 dengan kode warna kuning), dan Kehamilan Risiko Sangat Tinggi (jumlah skor 12 dengan kode warna merah). Skor yang digunakan adalah angka bulat dibawah angka 10 yaitu 2, 4, 8 . Skor awal ibu hamil adalah 2 dan tiap faktor risiko memiliki skor 4 kecuali pada riwayat sectio caesarea, letak sungsang, letak lintang, perdarahan antepartum, preeklampsia berat dan eklampsia (Prawirohardjo, 2010).

Peran determinan kematian ibu sebagai keadaan atau kondisi yang melatarbelakangi dan menjadi penyebab langsung maupun tidak langsung dari kematian ibu (Prawirohardjo, 2010). Kematian ibu dapat 
terjadi sebagai akibat langsung dari komplikasi yang berkembang pada kehamilan, persalinan atau faktor postpartum. Namun tidak menutup kemungkina bahwa masih banyak faktor penyebab tidak langsung kematian ibu terkait dengan faktor akses, sosial budaya, pendidikan, dan ekonomi.

\section{METODE}

Desain survei analitik dengan rancangan cross sectional corelasional dilakukan pada penelitian ini. Penelitian ini dilakukan pada tanggal 14 Desember 201527 Januari 2016 di RSUD Panembahan Senopati Bantul.

Jumlah populasi dalam penelitian ini adalah $2683 \mathrm{ibu}$ bersalin yang di rawat di RSUD Panembahan Senopati Bantul selama tahun 2014. Sampel diambil dari data rekam medik yang memenuhi kriteria inklusi dengan jumlah sampel 336 subjek. Nilai prevalensi 47,8\% didapatkan dari penelitian Oster Suriani Simarmata. Teknik pengambilan sampel secara non randomized dan teknik pengumpulan data menggunakan Kartu Skor Poedji Rochjati (KSPR) dan format pengumpul data.

Variabel bebas penelitian ini adalah tingkat risiko kehamilan dan variabel terikatnya adalah kejadian komplikasi persalinan. Sedangkan varibel penganggu dalam penelitian ini adalah tingkat pendidikan, pekerjaan, status perkawinan, dan riwayat penggunaan KB. Analisis data dilakukan secara univariabel, bivariabel menggunakan uji Chi Square, Ratio Prevalence (RP) dan multivariabel menggunakan uji regresi logistik.

\section{HASIL DAN PEMBAHASAN}

1. Analisis Univariat

Tabel 1.1 Karakteristik Subjek Penelitian

\begin{tabular}{cllcc}
\hline No & \multicolumn{1}{c}{ Karakteristik } & $\begin{array}{c}\text { Jumlah } \\
\text { (orang) }\end{array}$ & $\begin{array}{c}\text { Presentase } \\
\text { (\%) }\end{array}$ \\
\hline 1 & Tingkat & Tidak tamat SD & 1 & 0,3 \\
& Pendidikan & SD & 36 & 10,7 \\
& & SMP & 85 & 25,3 \\
& & SMA & 177 & 52,7 \\
\multirow{2}{*}{2} & \multirow{2}{*}{ Pekerjaan } & Perguruan Tinggi & 37 & 11 \\
& & Ibu Rumah Tangga & 201 & 59,8 \\
& & Buruh & 35 & 10,4 \\
& & Petani & 3 & 0,9 \\
& Pedagang & 3 & 0,9 \\
\hline
\end{tabular}

Tabel 1.1 (lanjutan) Karakteristik Subjek Penelitian

\begin{tabular}{llccc}
\hline No. & Karakteristik & $\begin{array}{c}\text { Jumlah } \\
\text { (Orang) }\end{array}$ & $\begin{array}{c}\text { Presentase } \\
\text { (\%) }\end{array}$ \\
\hline \multirow{4}{*}{} & & Pegawai/Karyawan & 34 & 10,1 \\
& & Wiraswasta/ Swasta & 47 & 14 \\
3 & PNS & 13 & 3,9 \\
4 & Status & Tidak Menikah & 7 & 2,1 \\
& Perkawinan & Menikah & 329 & 97,9 \\
& Riwayat & Tidak KB & 222 & 66,1 \\
& Penggunaan & Suntik & 85 & 25,3 \\
& KB & Pil & 18 & 5,4 \\
& & IUD & 8 & 2,4 \\
& & Kondom & 2 & 0,6 \\
& & Implant & 1 & 0,3 \\
\hline
\end{tabular}

Tabel 1.2 Distribusi Frekuensi Subjek

\begin{tabular}{lllll}
\hline No & & Variabel & $\begin{array}{l}\text { Jumlah } \\
\text { (orang) }\end{array}$ & $\begin{array}{l}\text { Presentase } \\
\text { (\%) }\end{array}$ \\
\hline $\mathbf{1}$ & Tingkat & KRST & 112 & 33,3 \\
& $\begin{array}{l}\text { Resiko } \\
\text { Kehamilan }\end{array}$ & KRT & 112 & 33,3 \\
& KRR & 112 & 33,3 \\
2 & Kejadian & Tidak Terjadi & 144 & 42,9 \\
& Komplikasi & Partus Lama & 61 & 18,2 \\
& Persalinan & Ketuban Pecah & 40 & 11,9 \\
& & Dini & & \\
& & Pendarahan & 13 & 3,9 \\
& & Infeksi & 5 & 1,5 \\
& & Preeklampsia & 21 & 6,3 \\
& & Berat & & \\
& & Komplikasi & 52 & 15,5 \\
& Lain & & \\
\hline
\end{tabular}

2. Analisis Bivariat

Tabel 2.1. Hubungan Karakteristik Subjek dengan Kejadian Komplikasi Persalinan

\begin{tabular}{|c|c|c|c|c|c|}
\hline \multirow[b]{2}{*}{ Karakteristik } & \multicolumn{4}{|c|}{ Kejadian Komplikasi Persalinan } & \multirow[b]{2}{*}{$\begin{array}{c}P \\
\text { Value }\end{array}$} \\
\hline & Terjadi & $\%$ & $\begin{array}{c}\text { Tidak } \\
\text { Terjadi }\end{array}$ & $\%$ & \\
\hline \multicolumn{6}{|l|}{ Pendidikan } \\
\hline Tinggi & 113 & 33,6 & 102 & 30,35 & \\
\hline Rendah & 79 & 23,5 & 42 & 12,5 & 0,024 \\
\hline \multicolumn{6}{|l|}{ Pekerjaan } \\
\hline Bekerja & 69 & 20,5 & 64 & 19,0 & \\
\hline Tidak Bekerja & 123 & 36,6 & 80 & 23,8 & 0,115 \\
\hline \multicolumn{6}{|l|}{ Status } \\
\hline \multicolumn{6}{|l|}{ Perkawinan } \\
\hline Menikah & 188 & 56 & 141 & 42 & \\
\hline Tidak Menikah & 4 & 1,2 & 3 & 0,89 & 1,000 \\
\hline \multicolumn{6}{|l|}{ Riwayat KB } \\
\hline KB & 65 & 19,3 & 49 & 14,6 & \\
\hline Tidak KB & 127 & 38 & 95 & 28,3 & 0,973 \\
\hline
\end{tabular}

Tabel 2.2 Hubungan Tingkat Risiko Kehamilan dengan Kejadian Komplikasi Persalinan

\begin{tabular}{|c|c|c|c|c|c|c|}
\hline \multirow[t]{2}{*}{ No } & \multirow{2}{*}{$\begin{array}{c}\text { Tingkat } \\
\text { Risiko } \\
\text { Kehamilan }\end{array}$} & \multicolumn{4}{|c|}{ Kejadian Komplikasi Persalinan } & \multirow{2}{*}{$\begin{array}{c}P \\
\text { value }\end{array}$} \\
\hline & & Terjadi & $\%$ & $\begin{array}{c}\text { Tidak } \\
\text { Terjadi }\end{array}$ & $\%$ & \\
\hline 1 & KRST & 82 & 24,4 & 30 & 8,9 & \\
\hline 2 & KRT & 67 & 19,9 & 45 & 13,4 & 0,000 \\
\hline 3 & KRR & 43 & 12,8 & 69 & 20,5 & \\
\hline
\end{tabular}


Hubungan Tingkat Risiko Kehamilan dengan Kejadian Komplikasi ...

Tabel 2.3 Ratio Prevalence

\begin{tabular}{|c|c|c|c|c|c|c|c|}
\hline \multirow{2}{*}{$\begin{array}{l}\text { Kategori Tingkat } \\
\text { Risiko Kehamilan }\end{array}$} & \multicolumn{4}{|c|}{ Kejadian Komplikasi Persalinan } & \multirow[t]{2}{*}{$\begin{array}{c}\mathrm{P} \\
\text { Value }\end{array}$} & \multirow[t]{2}{*}{$\begin{array}{c}\mathrm{X} 2 \\
\text { Hitung }\end{array}$} & \multirow[t]{2}{*}{$\begin{array}{c}\mathrm{RP} \\
\text { (CI 95\%) }\end{array}$} \\
\hline & Terjadi & $\%$ & $\begin{array}{c}\text { Tidak } \\
\text { Terjadi }\end{array}$ & $\%$ & & & \\
\hline KRST & 82 & 36,6 & 30 & 13,4 & 0,000 & 27,53 & 4,386 \\
\hline KRR & 43 & 19,2 & 69 & 30,8 & & & $\begin{array}{l}(2,491- \\
7,722)\end{array}$ \\
\hline KRST & 82 & 36,6 & 30 & 13,4 & 0,034 & 4,51 & 1,836 \\
\hline KRT & 67 & 29,9 & 45 & 20,1 & & & $\begin{array}{l}(1,045- \\
3,225)\end{array}$ \\
\hline $\begin{array}{l}\text { KRT } \\
\text { KRR }\end{array}$ & $\begin{array}{l}67 \\
43\end{array}$ & $\begin{array}{l}29,9 \\
19,2\end{array}$ & $\begin{array}{l}45 \\
69\end{array}$ & $\begin{array}{l}20,1 \\
31\end{array}$ & 0,001 & 10,28 & $\begin{array}{l}2,389 \\
(1,397- \\
4,085)\end{array}$ \\
\hline
\end{tabular}

3. Analisis Multivariat

Tabel 3. Hubungan Tingkat Risiko Kehamilan dan Tingkat Pendidikan dengan Kejadian Komplikasi Persalinan

\begin{tabular}{|c|c|c|c|c|c|}
\hline \multirow[t]{2}{*}{ Variabel } & \multicolumn{2}{|c|}{$\begin{array}{c}\text { Kejadian } \\
\text { Komplikasi } \\
\text { Persalinan } \\
\end{array}$} & \multirow[t]{2}{*}{$\begin{array}{c}P \\
\text { value }\end{array}$} & \multirow[t]{2}{*}{$\begin{array}{c}\operatorname{Exp} \\
(B)\end{array}$} & \multirow[t]{2}{*}{$\begin{array}{c}95 \% \\
\text { CI }\end{array}$} \\
\hline & B & SE & & & \\
\hline $\begin{array}{l}\text { Tingkat } \\
\text { Risiko } \\
\text { Kehamilan }\end{array}$ & 0,709 & 0,149 & 0,000 & 2,032 & $\begin{array}{l}1,517- \\
2,722\end{array}$ \\
\hline $\begin{array}{l}\text { Tingkat } \\
\text { Pendidikan }\end{array}$ & 0,229 & 0,250 & 0,359 & 0,795 & $\begin{array}{l}0,487- \\
1,298 \\
\end{array}$ \\
\hline
\end{tabular}

\section{Pembahasan}

\section{Karakteristik Subjek Penelitian}

Berdasarkan tabel 1.1 sebagian besar $52,7 \%$ berpendidikan sma. Penelitian ini berbeda dengan penelitian oster suriani simarmata dalam analisis data sekunder riset kesehatan tahun 2010 yang menunjukkan bahwa sebagian besar $41,2 \%$ subjek berpendidikan sd. Beberapa ahli berpendapat bahwa tinggi atau rendahnya pendidikan seorang ibu hamil akan berpengaruh terhadap kemampuannya menyerap informasi baru. Hal ini juga berdampak pada pengetahuan terhadap kondisi dan janinnya apakah berisiko atau tidak (simarmata, 2010).

Pekerjaan adalah status kegiatan atau pekerjaan ibu hamil sehari-hari sehingga mendapatkan penghasilan. Berdasarkan tabel 1.1 menunjukkan bahwa jumlah sebagian besar ibu tidak bekerja adalah 201 subjek (59,8\%). Penelitian ini sejalan dengan penelitian Yani di Puskesmas Nanggalo Padang yaitu sebagian besar 59,8\% ibu tidak bekerja (Maidelwita, 2010). Tingginya angka ibu yang tidak bekerja di RSUD Panembahan Senopati Bantul disebabkan oleh ibu hamil yang menjadi ibu rumah tangga dimana pada umumnya yang bekerja adalah suami.

Status pernikahan subyek dalam penelitian ini sebagiab besar adalah menikah $(97,9 \%)$. Status pernikahan mempunyai hubungan dalam reaksi emosional dan psikologik terhadap keadaan gawat darurat sehingga dibutuhkan komunikasi yang baik serta rasa empati dari tenaga kesehatan dalam menangani kasus tertentu (Prawirohardjo, 2010).

Berdasarkan tabel 1.1 menunjukkan bahwa jumlah sebagian besar $66,1 \%$ subyek tidak KB. Penelitian ini tidak sejalan dengan penelitian Diana di Kecamatan Parongpong Kabupaten Bandung Barat yang menunjukkan bahwa jumlah subyek yang tidak KB adalah 83 (31,2\%) (Diana, 2013) sehingga dalam penelitian ini dapat disimpulkan bahwa lebih dari 50\% ibu tidak ber-KB.

Program keluarga berencana (KB) sudah dicanangkan oleh pemerintah sejak tahun 1970an. Hal ini merupakan salah satu cara untuk menghindari terjadinya kematian maternal sehingga bagi ibu yang menggunakan $\mathrm{kb}$ dapat merencanakan dengan matang kehamilan dan 
persalinannya. Pencegahan kematian maternal dengan upaya penggunaan $\mathrm{KB}$ diharapkan dapat mewujudkan keluarga yang sehat dan sejahtera dengan cara membatasi dan atau menjarangkan kehamilan. Apabila ibu hamil dengan reproduksi sehat maka dapat mengurangi kejadian komplikasi obstetric baik pada ibu maupun pada bayi.

\section{Tingkat Risiko Kehamilan}

Berdasarkan tabel 2.2 diketahui bahwa masing-masing tingkat risiko kehamilan berjumlah 112 subyek. Tingkat risiko kehamilan KRST yang mengalami kejadian komplikasi persalinan adalah 82 subyek (24,4\%), KRT 67 subyek $(19,9 \%)$, dan KRR 43 subyek (12,8\%).

Pendekatan perawatan pada ibu hamil merupakan upaya yang harus dilakukan secara berkesinambungan melalui peningkatan kesehatan promotif, preventif, kuratif, rehabilitatif. (Ambarwati et al., 2011). Deteksi dini (skrinning) sedini mungkin pada awal kehamilan dapat dilakukan oleh petugas kesehatan atau non kesehatan misalnya PKK, kader posyandu, karang taruna, ibu hamil sendiri, suami atau keluarga agar dapat mengenali adanya kehamilan risiko tinggi.

Menurut poedji rochjati dalam obstetric modern, adanya potensi risiko kehamilan dan persalinan kemungkinan akan berpengaruh terhadap risiko terjadinya komplikasi pada persalinan dan komplikasi atau kegawatan pada persalinan juga dapat dipengaruhi oleh derajat faktor risiko. Apabila semakin tinggi tingkatan risiko faktor risiko pada ibu hamil maka semakin tinggi juga ibu akan mengalami komplikasi. Selain itu, faktor predisposisi juga dapat mempengaruhi tingkat risiko kehamilan antara lain pengetahuan, faktor sosial ekonomi juga dapat berpengaruh pada gizi ibu hamil yaitu tentang biaya dalam perawatan kehamilan dan persalinan (prawirohardjo, 2010).

Ukuran tingkat risiko kehamilan dalam penelitian ini dituangkan dalam angka yang disebut skor (prawirohardjo, 2010).
Menurut beberapa ahli menyatakan bahwa seorang ibu hamil dapat mempunyai faktor risiko tunggal, ganda dua, tiga ataupun lebih yang tampak dalam perhitungan jumlah skor dan dengan pengaruh risiko sinergistik dan kumulatif terjadinya komplikasi yang lebih berat (ummah, 2015).

\section{Kejadian Komplikasi Persalinan}

Berdasarkan tabel 2.1 tingkat pendidikan subjek dalam penelitian ini di kategorikan menjadi dua yaitu pendidikan tinggi (meliputi SMA, dan perguruan tinggi) dan pendidikan rendah (meliputi tidak sekolah, SD dan SMP). Hasil analisis bivariat menunjukkan bahwa 33,6\% kejadian komplikasi persalinan terjadi pada pendidikan tinggi dan nilai $\mathrm{p}$ value 0,024; $\mathrm{RP}=0,589 ; \quad 0,372-0,933$ dengan nilai signifikansi $=5 \%(0,05)$ sehingga dapat diambil kesimpulan bahwa H0 ditolak, artinya ada hubungan yang signifikan antara tingkat pendidikan dengan kejadian komplikasi persalinan di RSUD Panembahan Senopati Bantul tahun 2014.

Penelitian ini berbeda dengan penelitian yang dilakukan oleh Simarmata dalam Analisis Data Sekunder Riset Kesehatan Dasar 2010 yang menunjukkan bahwa sebagian besar kejadian komplikasi persalinan adalah subjek dengan pendidikan rendah sebesar $48,1 \%$. Nilai $p$ value 0,309 ; $\mathrm{RP}=1,04 ; 0,97-1,11)$ dengan nilai signifikansi

$=5 \% \quad(0,05)$ sehingga dapat diambil kesimpulan bahwa H0 diterima, artinya tidak ada hubungan yang signifikan antara tingkat pendidikan dengan kejadian komplikasi persalinan (Simarmata, 2014)

Pendidikan merupakan determinan konsektual dalam morbiditas dan mortalitas maternal (Prawirohardjo, 2010). Pendidikan seseorang juga merupakan faktor demografi yang berpengaruh terhadap kondisi kesehatan individu maupun masyarakat sehingga mempengaruhi akses dan pemanfaatan pelayanan kesehatan (Simarmata, 2014).

Pada tabel 2.1 pekerjaan subjek dalam penelitian ini di kelompokkan menjadi dua yaitu bekerja dan tidak bekerja. Hasil analisis 
bivariat menunjukkan bahwa 36,6\% kejadian komplikasi persalinan terjadi pada subjek yang tidak bekerja dan didapatkan nilai $\mathrm{p}$ value 0,$115 ; \mathrm{RP}=0,701 ; 0,451-1,090$ dengan nilai signifikansi $=5 \%(0,05)$ sehingga dapat diambil kesimpulan bahwa H0 diterima, artinya tidak ada hubungan yang signifikan antara pekerjaan dengan kejadian komplikasi persalinan.

Penelitian ini berbeda dengan penelitian Fajrin (2009) yang menunjukkan bahwa sebagian besar kejadian komplikasi persalinan terjadi pada subyek yang bekerja, dengan nilai $\mathrm{p}$ value 0,870 sehingga dapat diambil kesimpulan bahwa $\mathrm{H} 0$ diterima, artinya tidak ada hubungan antara pekerjaan dengan kejadian komplikasi persalinan. Dengan melihat nilai $\mathrm{p}$ value penelitian ini dengan penelitian Fajrin (2009) yaitu keduanya sama- sama tidak ada hubungan antara kedua variabel.

Dalam penelitian ini mayoritas subjek yang terjadi komplikasi persalinan adalah ibu yang tidak bekerja maupun ibu rumah tangga. Hal ini dapat kemungkinan disebabkan karena ibu yang tidak bekerja tidak memiliki pengetahuan dan pengalaman yang diperoleh dari lingkungan pekerjaan dan media serta fasilitas pendukung yang ada ditempat kerja mereka. Kurangnya informasi-informasi mengenai kesehatan dan rasa keinginan tahuan yang kurang dapat memicu terjadi rendahnya kesadaran mengenai pentingnya mengetahui kondisi ibu hamil.

Status pernikahan pada penelitian ini, sebagian besar kejadian komplikasi persalinan terjadi pada menikah dengan nilai $\mathrm{p}$ value 1,$000 ; \mathrm{RP}=1,000 ; 0,220-4,539$ dengan nilai signifikansi $=5 \%(0,05)$ yang berarti tidak ada hubungan antara status pernikahan dengan kejadian komplikasi persalinan di rsud panembahan senopati bantul tahun 2014.

Riwayat KB subjek dalam penelitian ini dikategorikan menjadi dua yaitu KB dan tidak KB. Pada tabel 2.1 menunjukkan bahwa kejadian komplikasi sebagian besar terjadi pada subyek yang tidak $\mathrm{kb}$ yaitu sebesar 37,8\% dengan nilai p value 0,973 ;
$\mathrm{RP}=0,992 ; 0,629-1,566$ yang disimpulkan bahwa tidak ada hubungan antara riwayat penggunaan $\mathrm{kb}$ dengan kejadian komplikasi persalinan di rsud panembahan senopati bantul tahun 2014.

Banyaknya kejadian komplikasi persalinan pada kategori tidak KB bisa disebabkan oleh banyak faktor salah satunya adalah paritas dan jarak kelahiran. Dalam penelitian yang dilakukan oleh Mohamed Alsamani dan salah rushdy ahmed (2015) menunjukkan bahwa sebagian besar kehamilan dengan multipara mempunyai risiko komplikasi kebidanan. Sehingga untuk menghindari terjadinya komplikasi pada kehamilan, persalinan ataupun nifas maka program pemerintah indonesia menganjurkan untuk mempunyai dua anak. Oleh sebab itu, program kb secara tidak langsung dapat mengurangi risiko kematian ibu (kemenkes ri, 2014).

Hubungan tingkat risiko kehamilan
terhadap kejadian komplikasi persalinan Pada tabel 2.2 tingkat risiko kehamilan dalam penelitian ini mempunyai hubungan yang signifikan dan dianggap bermakna secara statistik karena $\mathrm{p}$ value 0,000 . Hasil ini secara statistik menunjukkan bahwa h0 ditolak, yang berarti ada hubungan antara tingkat risiko kehamilan dengan kejadian komplikasi persalinan.

Penelitian ini sesuai dengan penelitian simarmata (2014) yang menyebutkan bahwa ibu yang mengalami komplikasi pada kehamilan memiliki hubungan yang signifikan dengan kejadian komplikasi persalinan (or $=2,72,95 \%$ ci 2,34 $3,17)$, dimana ibu yang mengalami komplikasi selama kehamilannya berisiko 2,72 kali mengalami komplikasi pada persalinannya dibandingkan ibu yang tidak mengalami komplikasi pada kehamilannya.

Hasil analisis yang paling signifikan pada tabel 2.3 adalah analisis kategori pertama dengan nilai $=5 \%(0,05) \mathrm{di}$ dapatkan $\mathrm{p}$ value $0,000 \times 2$ hitung 27,532 dan x2hitung $>$ x2tabel $(x 2=3,481)$ artinya terdapat hubungan yang signifikan antara tingkat risiko kehamilan krst dan krr dengan 
kejadian komplikasi persalinan. Ratio prevalence (RP) 4,4 yang artinya ibu dengan tingkat risiko krst 4,4 kali lebih berisiko terjadi komplikasi persalinan dibandingkan dengan ibu tingkat risiko KRR.

\section{Hubungan tingkat risiko kehamilan dan tingkat pendidikan dengan kejadian komplikasi persalinan}

Pada tabel 3 menunjukkan bahwa terdapat hubungan yang signifikan antara tingkat risiko kehamilan dengan kejadian komplikasi persalinan karena nilai $\mathrm{p}$ value 0,000 dengan nilai $=5 \%(0,05)$ dan mempunyai risiko 2 kali terjadi komplikasi persalinan. Pada analisis bivariat dengan mengontrol tingkat risiko kehamilan, tingkat pendidikan mempunyai hubungan yang signifikan. Namun, setelah dilakukan uji secara bersama tingkat pendidikan tidak terdapat hubungan yang signifikan dengan kejadian komplikasi persalinan karena nilai $\mathrm{p}$ value 0,359 dengan nilai $=5 \%(0,05)$.

Berdasarkan kerangka konsektual pendidikan termasuk kedalam status perempuan dalam keluarga dan masyarakat yang salah satunya dapat ditentukan oleh tingkat pendidikan. Determinan konsektual merupakan penyebab tidak langsung terjadinya kematian ibu. Sedangkan tingkat risiko kehamilan mempunyai hubungan yang signifikan terhadap kejadian komplikasi persalinan hal ini disebabkan karena tingkat risiko kehamilan termasuk ke dalam determinan proksi atau penyebab langsung sehingga hal ini, menempatkan perempuan hamil mempunyai risiko untuk mengalami komplikasi kebidanan (obstetric) yang dapat mengancam jiwanya karena tingkat risiko kehamilan memiliki risiko 2 kali terjadi komplikasi pada saat persalinan (prawirohardjo, 2010).

\section{PENUTUP}

\section{Kesimpulan}

Berdasarkan hasil dalam penelitian ini dapat ditarik kesimpulan bahwa:

1. Sebagian besar subjek di RSUD Panembahan Senopati Bantul tahun 2014 berpendidikan SMA, ibu rumah tangga, menikah, dan tidak KB.

2. Sebagian besar kejadian komplikasi persalinan di RSUD Panembahan Senopati Bantul tahun 2014 adalah partus lama.

3. Tingkat risiko kehamilan memiliki hubungan yang signifikan dengan kejadian komplikasi persalinan di RSUD Panembahan Senopati Bantul tahun 2014.

4. Semakin tinggi tingkat risiko kehamilan maka semakin tinggi pula kejadian komplikasi persalinan.

\section{Saran}

1. Bidan Pelaksana di Rumah Sakit Untuk bidan agar dapat melakukan skrinning atau deteksi dini sesuai dengan kondisi dan faktor risiko yang ada pada ibu hamil sehingga dapat mencegah terjadinya komplikasi persalinan.

2. Dinas Kesehatan Meningkatkan kualitas program antenatal care dengan cara melakukan pembinaan secara terpadu pada tenaga kesehatan agar memperhatikan ibu hamil yang mempunyai faktor risiko sehingga dapat mengantisipasi terjadinya komplikasi persalinan.

\section{DAFTAR PUSTAKA}

Alsamani, Mohamed Akhatim and Salah Roshdy Ahmed. Grand Multiparity Risk Factors and Outcome in a Tertiary Hospital a Comparative Study. Original Paper. Mater Sociomed. 2015 Aug 27 (4): 244-247.

Ambarwati, Maria Retno, Rita Yuliana, Nurwening Tyas Wisnu. (2011). Gambaran Faktor Penyebab Ibu Hamil Resiko Tinggi Tahun 2005-2010 di Polindes Sambikerep Kecamatan Rejoso Kabupaten Nganjuk. Jurnal Penelitian Kesehatan Suara Forikes. Volume II Nomor Khusus Hari Kesehatan Nasional. ISSN: 2086-3098.

Badan Penelitian dan Pengembangan Kesehatan Kementrian RI. Riset Kesehatan Dasar 2013. Bhakti Husada.

Badan Kependudukan dan Keluarga Berencana Nasional Badan Pusat 
Statistik Kementerian Kesehatan. (2013). Survei Demografi Dan Kesehatan Indonesia 2012.

Basu ,M, S. Mukerji, S. K. Doumouchtsis. (2014). Perineal Trauma in Women Undergoing Vaginal Delivery Following Intra-Uterine Fetal Demise: A CaseControl Analysis. Original Article: Int Urogynecol J 25:61-64. DOI 10.1007/s00192-013-2148-1.

Cruickshank, Maaggie, Ashalatha Shetty. (2009). Obstetrics and Gynecology Clinical Cases Uncovered. USA: Wiley Blackwell.

Diana, Hadyana Sukandar dan Budi Handono. (2013). Analisis Faktor-Faktor yang Berhubungan dengan Komplikasi Obstetri Ibu dan Bayi di Kecamatan Parongpong Kabupaten Bandung Barat. Tesis. Universitas Padjajaran.

Dinas Kesehatan Daerah Istimewa Yogyakarta. (2014). Profil Kesehatan DIY.

Direktorat Bina Kesehatan Ibu Ditjen Bina Gizi dan KIA Kementerian Kesehatan RI. (2013). Rencana Aksi Percepatan Penurunan Angka Kematian Ibu Di Indonesia. Jakarta: Bhakti Husada.

Fajrin, Itsna Nofianti. (2009). Faktor-Faktor yang Berhubungan dengan Kejadian Komplikasi Persalinan di Rumah Sakit Roemani Kota Semarang Tahun 2008. Skripsi.

Gilles Kayem, Jennifer Kurinczuk, Gwyneth Lewis, Shona Golightly, Peter Brocklehurst, Marian Knight. (2011). Risk Factors for Progression from Severe Maternal Morbidity to Death: A National Cohort Study. PLoS ONE 6(12):e29077.doi:10.1371/journal.pone.0 029077.

Kementrian Kesehatan RI. (2014). Infodatin Pusat Data dan Informasi Situasi Kesehatan Ibu.

Kementerian Perencanaan Pembangunan Nasional. (2014). Agenda Pembangunan Bidang. Rancangan Awal Rencana Pembangunan Jangka Menengah Nasional 2015-2019.
Leveno, Kenneth J, F. Garu Cuningham, Norman F. Gant, et al. Obstetri Williams Panduan Ringkas Edisi 21. Jakarta: EGC.

Maidelwita, Yani. (2010). Faktor- Faktor yang berhubungan dengan Kehamilan Risiko Tinggi di Puskesmas Nanggalo Padang. Skripsi. Stikes Mercubaktijaya Padang.

Medforth, Janet, Susan Battersby, Maggie Evans, Beverley Marsh and Angela Walker. (2010). Kebidanan Oxford Dari Bidan Untuk Bidan. Jakarta: EGC.

Moedjiarto, Sarmini. (2011). Karakteristik Ibu yang Berhubungan dengan Perdarahan Post Partum di Rumah Bersalin Medika Utama Wonokupang Balongbendo Sidoarjo Tahun 2009. Volume 3 No. I Februari 2011.

Mochtar, Rustam. (2011). Sinopsis Obstetri Edisi 3. Jakarta: EGC.

Mulyawati, Isti, Mahalul Azam, Dina Nur Anggraini Ningrum. Faktor Tindakan Persalinan Operasi Sectio Caesarea. Kemas 7 (1) (2011) 14-ISSN 1858-1196.

Mufdillah. (2009). Panduan Asuhan Kebidanan Ibu Hamil. Yogyakarta: Nuha Medika.

North, Robyn A, Lesley M E Mc Cowon, Gustaaf A Dekker, Lucilla Poston, et al. Clinical Risk Prediction for Preeclampsia in Nulliparous Women: Development of Model in International Prospective Cohort. BMJ 2011:342:d1875.

Pramono, Mohammad Setyo dan Astridya Paramita. (2014). Pola Kejadian dan Determinan Bayi dengan Berat Badan Lahir Rendah (BBLR) di Indonesia Tahun 2013. Buletin Penelitian Sistem Kesehatan. Vol. 18 No. 1 Januari 2015; 110.

Prakarsa. (2013). Angka Kematian Ibu (AKI) Melonjak Indonesia Mundur 15 Tahun. Laju Penurunan Kematian Ibu di Indonesia terburuk dari negara-negara miskin di Asia. Prakarsa Policy Review.

Pratiknya, Ahmad Watik. (2013). DasarDasar Metodologi Penelitian Kedokteran dan Kesehatan. Jakarta: PT Raja Grafindo Persada. 
Hubungan Tingkat Risiko Kehamilan dengan Kejadian Komplikasi ...

Prawirohardjo, Sarwono. 2010. Ilmu Kebidanan. Jakarta: Yayasan Bina Pustaka Sarwono Prawirohardjo.

Pribadi, F. Garry, Norman F.Gant, Kenneth J Leveno. (2010). Obstetri Williams Edisi 21. Jakarta: EGC.

Riwidikdo, Handoko. (2012). Statistik Kesehatan. Yogyakarta: Nuha Medika.

Sadi, Muhammad. (2015). Etika dan Hukum Kesehatan. Jakarta: Prenadamedia Group.

Sastroasmoro, Sudigdo dan Sofyan Ismael. (2011). Dasar-Dasar Metodologi Penelitian Klinis. Jakarta: Sagung Seto.

Simarmata, Oster Suriani, et al. (2014). Determinan Kejadian Komplikasi Persalinan di Indonesia: Analisis Data Sekunder Riset Kesehatan Dasar 2010 Depok: Teknologi Intervensi Kesehatan Masyarakat. Jurnal Kesehatan Reproduksi Volume 5 No. 3.

Sugiyono. (2010). Statistika untuk Penelitian. Bandung: Alfabeta.

Swarja, I Ketut. (2013). Metodologi Penelitian Kesehatan. Yogyakarta: Andi

Supangat, Andi. (2008). Statistika Dalam Kajian Deskriptif, Inferensi dan Nonparametrik. Jakarta: Kencana.
Susilo dan Suryanto. (2014). Metodologi Penelitian Cross Sectional Kedoteran dan Kesehatan.Klaten: Boss Script.

Ummah, Faizatul. Kontribusi Faktor Risiko I Terhadap Komplikasi Kehamilan Di Rumah Sakit Muhammadiya Surabaya. Volume 07, No.01, April 2015.

Varney, Helen, Jan M. Kriebs, Carolyn L. Gegor. (2004). Buku Ajar Asuhan Kebidanan Edisi 4 Volume 2. Jakarta: EGC.

Vistad, Ingvild, Milada Cvancarova, Berit L Hustad and Tore Henriksen et al. Vaginal breech delivery: results of a prospective registration study. Vistad BMC Pregnancy and Childbirth 2013, 13:153.

http://www.biomedcentral.com/14712393/13/153

WHO, UNICEF, UNFPA, The World Bank and The United Nations Population Division. (2014). Trends in Maternal Mortality 1990 to 2013. ISBN:9789241507226. 